\title{
Sustainable Business Models: Literature Review of Main Contributions and Themes
}

\author{
Cantele Silvia ${ }^{1} \&$ Serena Truzzi ${ }^{1}$ \\ ${ }^{1}$ Department of Business Administration, University of Verona, Italy \\ Correspondence: Silvia Cantele, Department of Business Administration, Via Cantarane 24, Verona, 37129, Italy. \\ E-mail: silvia.cantele@univr.it
}

Received: February 10, 2019

Accepted: March 18, 2020

Online Published: April 8, 2020

doi:10.5539/ijbm.v15n5p11

URL: https://doi.org/10.5539/ijbm.v15n5p11

\begin{abstract}
Literature on sustainable business models (SBM) has recently emerged and is rapidly expanding. This promising research field is aimed at intersecting traditional business model approaches with corporate sustainability. Most of the research to date has focused on existing case studies or examples of sustainability innovations in business models or on the use of frameworks and tools to categorise or design SBMs or suggest the stages of this innovative process towards sustainability. This article presents an integrative literature review aimed at describing the objective aspects of the SBM literature such as its temporal, industrial, geographical and methodological factors. As well as this descriptive analysis, the paper categorises the SBM literature in terms of its main purposes and themes. This categorisation is aimed at synthesising the main contributions of the SBM literature and to highlight gaps to suggest possible further developments. Despite presenting different perspectives on value (proposition, creation, delivery and capture), the current research on SBM has failed to take a holistic approach towards sustainable value measurement and representation in its models and frameworks.
\end{abstract}

Keywords: sustainable business models, business model for sustainability, literature review, value, sustainability

\section{Introduction}

Sustainability is one of the major challenges of our time, reflected by the increasing focus of the public, governments and organisations on issues such as climate change, poverty, inequalities and the unsustainable use of resources (United Nations, 2015). Therefore, companies are faced with a major challenge to adapt, modify or transform their business models (BMs) to seize the opportunities and face the threats that characterise an environment in continuous change (Moratis, Melissen, \& Idowu, 2018). In this light, companies should adopt BMs that contribute to sustainable development, which is defined as development capable of satisfying the needs of current generations without compromising the needs of future generations (World Commission on Environment and Development, 1987). Over the past decade, literature on sustainable business models (SBMs) has increased considerably because of growing concerns over global, social and environmental problems. Research on SBMs is relatively recent compared with research on BMs, which has been a common topic of research in the academic and professional world since the advent of the internet in 1995. Indeed, research on BMs has been popular since the dotcom era and the rise of electronic commerce (Richardson, 2008).

The literature presents many definitions of BMs. According to Osterwalder, Pigneur and Tucci (2010), a BM expresses the logic through which an organisation creates, delivers and retains value. Starting from this concept, typical BM elements include the following: (i) value proposition, or the offer of value to the customer, which includes not only the products and services supplied by the firm but also the targets to which they are aimed and the strategies adopted to acquire new or retain existing customers; (ii) the value creation and delivery system, which is the means through which an enterprise creates value through its own activities and distributes it to partners, suppliers and other stakeholders; and (iii) so-called value capture, which is how an enterprise generates profit through the value that it retains for itself in relation to the generated value, allowing the firm to endure over time (Richardson, 2008).

The literature on SBMs (Bocken, Short, Rana, \& Evans, 2014; Stubbs \& Cocklin, 2008) and BMs for sustainability (BMfS) (Schaltegger, Hansen, \& Lüdeke-Freund, 2016a), (Schaltegger, Hansen, \& Lüdeke-Freund, 2016b) originated from the general BM research. Despite its recency, the SBM literature presents some differentiating elements, even though most contributions have been devoted to providing theoretical definitions of SBM and 
BMfS concepts, analysing the components of SBM or presenting empirical research from the perspective of case studies. SBMs have been defined as BMs that incorporate the proactive management of monetary and non-monetary value creation for a wide range of stakeholders from a long-term perspective (Geissdoerfer, Vladimirova, \& Evans, 2018). They are also defined as models in which the principles of sustainability guide companies in decision-making processes (Stubbs \& Cocklin, 2008). A BMfS is a model that describes, analyses, manages and communicates a firm's value proposition to its stakeholders and how that value is created, delivered and retained, while maintaining or increasing natural, social and economic capital (Schaltegger et al., 2016a, 2016b). In contrast, some authors have proposed other classifications of SBMs, such as those presented by Dohrmann, Raith and Siebold (2015) and Tukker (2004), the ideal types proposed by Stubbs and Cocklin (2008), the archetypes of Bocken et al. (2014) and the patterns of Lüdeke-Freund, Carroux, Joyce, Massa and Breuer (2018).

Another relevant stream of research is focused on SBM design and aims to develop tools that companies may use to innovate their BMs towards sustainability. Scholars have attempted to modify Osterwalder et al.'s (2010) business model canvas by incorporating three dimensions of sustainability. The triple layered business model canvas proposed by Joyce and Paquin (2016) adds two additional layers to the traditional canvas: The first layer concerns the environmental dimension, which refers to the environmental impacts generated at each stage of the life cycle of a product, while the second layer concerns the social dimension, with a particular focus on a company's stakeholders. After presenting a new ontology of BMs, Upward and Jones (2016) proposed the strongly sustainable business model canvas (Kurucz, Colbert, Lüdeke-Freund, Upward, \& Willard, 2017), later renamed the flourishing business model canvas (Hoveskog, Halila, Mattsson, Upward, \& Karlsson, 2018), which is a model that creates, delivers and retains positive economic, social and environmental value for all respective stakeholders through its value network, thus fostering the possibility for human and non-human life to flourish indefinitely on the planet (Ehrenfeld, 2000). Other recently proposed canvasses and tools include the value triangle framework (Biloslavo, Bagnoli, \& Edgar, 2018) and the sustainable value exchange matrix (Morioka, Bolis, Monteiro, \& Carvalho, 2018). With respect to empirical studies, the literature mainly presents qualitative analyses of case studies (Dentchev et al., 2018) with the aim of presenting state-of-the-art and best practices of pioneer SBM organisations.

The aim of this study is to present an integrative literature review of SBM research that focuses on various descriptive aspects of its evolution (i.e. year and journal of publication, type of study, methods of data collection and analysis and geographical and sectorial factors) and categorises the main purposes and contributions developed to date. Themes are developed based on recurring content to identify gaps and suggest pathways for future research.

The article is structured in five sections. Section 2 describes the methodology used to conduct a high-quality integrative literature review and illustrates the various steps leading to its realisation. Section 3 presents a descriptive analysis of the 104 collected articles in terms of their distribution by publication year and journal, type of article, the main methods of data collection and analysis and, with respect to empirical articles, the main industries and countries of firms analysed in each article. Section 4 provides our original contribution in terms of article classification according to each article's specific purpose and content. The final section summarises the main contributions of this research together with limitations and recommendations for future research on SBMs. In particular, it highlights a gap that emerged from our review regarding the measurement and representation of value delivery and capture in SBMs. In fact, value capture in current SBMs does not appear to have evolved from traditional financial BM canvasses, regardless of the numerous claims about the need to consider value not only from the financial perspective but also from the social and environmental perspective.

\section{Literature Review Method}

The integrative literature review is a specific research method that allows for the synthesis and critical analysis of a body of literature to highlight new perspectives and generate new knowledge of selected themes (Torraco, 2005).

Prior to conducting an integrative literature review, it is necessary to choose a theme to analyse and schedule the work by making a (flexible) plan that will act as a guide along the research path (Tranfield, Denyer, \& Smart, 2003). Topic identification and selection should arise from a need to review the literature such as a gap in the research or the reviewer's interest in the topic. In either case, authors should demonstrate their knowledge of the topic by clarifying the main concepts upon which the chosen theme is based, identifying authors who have carried out relevant studies in the area and highlighting the historical origins and fundamental stages in the evolution of the theme. In this way, even inexperienced readers will easily understand the topic of research (Luciano, 2011). 
An integrative literature review involves the following steps (Seuring \& Müller, 2008): First, appropriate materials must be collected, and the limits of the research and research unit established. Second, a descriptive analysis should be carried out to describe the formal aspects of materials collected (e.g. the number of publications by year) to provide a basis for the consequent theoretical analysis. Third, the collected documents should be categorised. Finally, the collected materials must be evaluated by considering their structural dimensions to highlight significant issues and help researchers interpret the results obtained from the investigation.

A literature review was conducted following these suggestions and guidelines, starting with the initial collection of data. Two keywords were selected for the bibliographic database search: 'sust* business model' (the asterisk was used to cover as many terms as possible) and 'business model for sustainability'. These search terms were selected based on their presence in the literature on BMs with a sustainability approach and were applied to three databases: EBSCO (www.ebsco.com), Scopus (www.scopus.com) and Web of Science (www.webofscience.com); these three databases were chosen because they represent the most relevant bibliographic databases for business research. Next, the field of investigation and limits of the research were defined. Initially, only titles of articles were searched for keywords, before expanding the search to include abstracts and keywords of the articles to increase the sample size. Moreover, criteria were selected to narrow the range of articles to those most relevant. First, the oldest year of publication was set to 2008, when a seminal work by Stubbs and Cocklin (2008) was published. Further inclusion criteria were only articles in English and those for which the full text in PDF was available. Finally, only articles published in scientific journals were selected, while books, theses and professional or commercial reports were excluded.

The initial quantitative review outputs were as follows. For EBSCO, the search term 'sust* business model' was found in the titles of 26 articles, the abstracts of 371 articles and keywords of 31 articles, for a total of 428 articles, while the search term 'business model for sustainability' was found in 13 titles, 159 abstracts and 15 keywords. For Scopus, we collected a total of 2,620 relevant articles, subdivided as follows: the search term 'sust* business model' was found in the titles of 96 articles, the abstracts of 1,415 articles and the keywords of 287 articles, while 'business model for sustainability' was found in the titles of 26 articles, the abstracts of 626 articles and the keywords of 170 articles. For the third and final database, articles were identified using 'topic' in the survey field, allowing us to search in titles, abstracts and article keywords for search terms. Using 'sust* business model', we found a total of 349 articles, and using 'business model for sustainability', we found 1,050 articles, for a total of 3,399 articles.

Article collection and selection took place from April to October 2019. Special issues published in the same period (2008-2019) were also collected (Agafonow, Donaldson, \& Hoerber, 2015; Arevalo et al., 2011; Boons, Montalvo, Quist, \& Wagner, 2013; Dentchev et al., 2016; Jabłoński, 2016b; Pedersen \& Gardetti, 2015; Schaltegger et al., 2016a; Svensson \& Wagner, 2011) to include any other articles not detected in the database search. Once the collection of relevant articles had been completed, a check was carried out to remove duplicates.

The final sample was obtained following systematic analysis and evaluation of the collected articles, beginning with a careful reading of abstracts and keywords with the aim of verifying whether the topic was consistent with that of the review. The sample of articles was then examined in more detail, with a particular focus on the theoretical frameworks used. Only articles citing literature on SBMs or BMfS were retained, while those referring to BMs in general (e.g. definitions and classification), sustainability as a general concept or financial sustainability were discarded. Articles referring to circular BMs were also excluded because their prevalence led us to consider this as a separate topic in the literature needing specific analysis in further research. The final sample consisted of 104 scholarly articles, which were examined in more detail to understand their contributions to the literature on SBMs and categorise them based on the following criteria: year of publication, journal of publication, type of article, data collection method, data analysis method and, for empirical studies, industry and country. To better understand their contributions to the literature, articles were classified according to their purpose and content. These categories were not predefined but emerged during article analysis based on the detection of recurring topics and approaches.

\section{Analysis of Diffusion Features and Methodological Aspects}

SBMs and BMfS are emerging themes that have only recently appeared in the literature (Torraco, 2005). Hence, the literature is not yet saturated, providing opportunities for researchers to offer new perspectives and suggestions to further develop the research field. As shown in Figure 1, the number of publications has increased sharply: one article was published in 2008 rising to three in 2014; however, since 2015, the number of publications has increased considerably, reaching a peak of 34 articles in 2018 before decreasing to nine in 2019. However, given 
that the data collection period ended in October 2019, the final year excludes those articles published from October to December 2019.

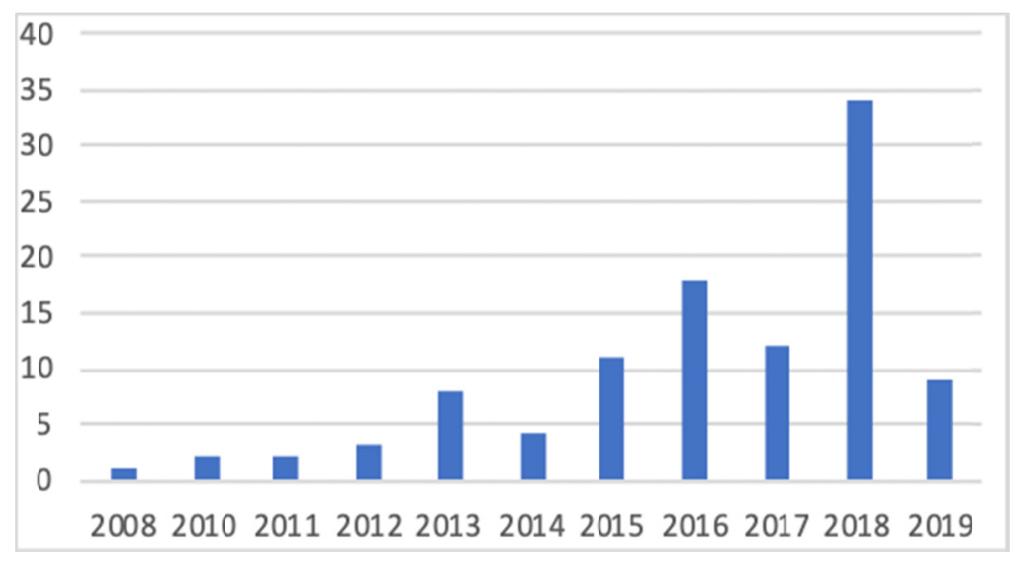

Figure 1. Number of articles by year

Table 1 shows the journals that have provided the most visibility to the SBM literature: Journal of Cleaner Production (46 articles on the topic published in recent years); Organization \& Environment (nine articles), Journal of Business Models (seven articles), Sustainability (six articles), Journal of Corporate Citizenship (five articles) and other journals with two articles each. Another 23 journals (not shown in Table 1) published only one article each.

Table 1. Number of articles by journal

\begin{tabular}{llc}
\hline Journal & Frequency & $\%$ of Frequency \\
\hline Journal of Cleaner Production & 46 & $44.23 \%$ \\
Organization \& Environment & 9 & $8.65 \%$ \\
Journal of Business Models & 7 & $6.73 \%$ \\
Sustainability & 6 & $5.77 \%$ \\
Journal of Corporate Citizenship & 5 & $4.81 \%$ \\
International Journal of Innovation Management & 2 & $1.92 \%$ \\
Long Range Planning & 2 & $1.92 \%$ \\
European Business Review & 2 & $1.92 \%$ \\
Business Strategy and the Environment & 2 & $1.92 \%$ \\
Others & 23 & $22.12 \%$ \\
Total & 104 & $100 \%$ \\
\hline
\end{tabular}

Table 2 reveals the types of articles in the sample. The majority (almost 60\%) comprised theoretical articles that presented at least one case study. These studies typically involved the application of pre-existing or new theoretical models to the case study or the participation of professionals or managers to discuss the models. The second most common type (22 articles) comprised theoretical articles that simply proposed modified or new frameworks or conceptual models without applying them, while a third theoretical type comprised literature reviews aimed at categorising SBMs (8 articles). The final category of articles (15) included all empirical studies in which the theoretical background was missing or presented as a pure premise for analysis. These articles focused mainly on the collection and the qualitative or, less frequently quantitative, analysis of empirical data (e.g. case studies of companies that have succeeded in orientating their BMs towards sustainability). 
Table 2. Frequency of articles by type

\begin{tabular}{llc}
\hline Type of article & Frequency & \% of Frequency \\
\hline Theoretical and case example & 59 & $56.73 \%$ \\
Theoretical & 22 & $21.15 \%$ \\
Empirical & 15 & $14.42 \%$ \\
Review & 8 & $7.69 \%$ \\
Total & 104 & $100 \%$ \\
\hline Tables 3 and 4 present the methods of data collection (Table 3) and analysis (Table 4) in more detail. Table 3 \\
shows that the most common data collection methods were from secondary data and interviews. Secondary data, \\
gathered in 56 articles, were collected from existing databases, company websites and internal documents and \\
various archives and reports. Primary data collected directly by researchers were most frequently generated by \\
interviews (51) and, to a lesser extent, surveys, workshops and focus groups. Participants involved in data \\
collection were mostly managers, professionals, experts or, in some cases, employees and consumers, depending \\
on the focus of the specific article.
\end{tabular}

Table 3. Methods of data collection

\begin{tabular}{llc}
\hline Method of data collection & Frequency & \% of Frequency \\
\hline Secondary data & 56 & $53.85 \%$ \\
Interview & 51 & $49.04 \%$ \\
Survey & 14 & $13.46 \%$ \\
Literature review & 13 & $12.50 \%$ \\
Workshop & 10 & $9.62 \%$ \\
Delphi method & 2 & $1.92 \%$ \\
Focus group & 2 & $1.92 \%$ \\
Action research & 2 & $1.92 \%$ \\
\hline
\end{tabular}

Table 4 shows the data analysis methods. Case studies were the most frequent method used (47 of 104 articles), allowing an in-depth analysis of the characteristics and critical success factors of specific firms that have transitioned towards an SBM. In order of frequency, case studies were followed by content analysis (30 of 104 articles) and coding procedures (25 of 104 articles), while few articles were found presenting quantitative analyses such as correlation analysis, analysis of variance, median tests or structural equation modelling.

Table 4. Methods of data analysis

\begin{tabular}{llc}
\hline Method of data analysis & Frequency & \% of Frequency \\
\hline Case study & 47 & $45.19 \%$ \\
Content analysis & 30 & $28.85 \%$ \\
Coding & 25 & $24.04 \%$ \\
Quantitative (analysis of variance, structural equation modelling, & 5 & $4.81 \%$ \\
correlation analysis, median tests) & 2 & $1.92 \%$ \\
Thematic analysis & 2 & $1.92 \%$ \\
System dynamics, network analysis & 2 & \\
\hline
\end{tabular}

Table 5 shows the number of articles presenting data from empirical or case studies in descending order of frequency according to industry. The most common sector was manufacturing, immediately followed by the energy and gas sector. Eighteen articles were on firms from the services sector, 17 from the food and beverage sector and 10 from the fashion industry. Relatively fewer articles pertained to the public, social and non-profit, agricultural, education, building, banking and financial, mobility and retail sectors. 
Table 5. Industries

\begin{tabular}{llc}
\hline Type of industry & Frequency & \% of Frequency \\
\hline Manufacturing & 28 & $26.92 \%$ \\
Energy and gas & 20 & $19.23 \%$ \\
Services & 18 & $17.31 \%$ \\
Food and beverage & 17 & $16.35 \%$ \\
Fashion & 10 & $9.62 \%$ \\
Public, social and non-profit services & 7 & $6.73 \%$ \\
Agriculture & 6 & $5.77 \%$ \\
Education & 6 & $5.77 \%$ \\
Building & 5 & $4.81 \%$ \\
Banking and financial services & 5 & $4.81 \%$ \\
Mobility & 4 & $3.85 \%$ \\
Retail & 2 & $1.92 \%$ \\
\hline
\end{tabular}

Finally, with regard to the geographical locations of the companies analysed in the articles, Table 6 shows that firms from United States, United Kingdom, Germany and Netherlands were represented most frequently. Apart from Australia, Brazil, Canada and China, the remaining articles presented empirical data mainly from European countries.

Table 6. Countries

\begin{tabular}{llc}
\hline Country & Frequency & \% of Frequency \\
\hline United States & 18 & $17.31 \%$ \\
United Kingdom & 14 & $13.46 \%$ \\
Germany & 13 & $12.50 \%$ \\
Netherlands & 11 & $10.58 \%$ \\
Sweden & 7 & $6.73 \%$ \\
Australia & 6 & $5.77 \%$ \\
Brazil & 5 & $4.81 \%$ \\
Switzerland & 5 & $4.81 \%$ \\
Canada & 4 & $3.85 \%$ \\
China & 4 & $3.85 \%$ \\
Finland & 4 & $3.85 \%$ \\
France & 4 & $3.85 \%$ \\
Austria & 3 & $2.88 \%$ \\
Denmark & 3 & $2.88 \%$ \\
Europe & 3 & $2.88 \%$ \\
Poland & 3 & $2.88 \%$ \\
Portugal & 3 & $2.88 \%$ \\
\hline
\end{tabular}

\section{Analysis of Main Contributions and Themes}

The previous section highlighted some descriptive characteristics of the articles included in the review, starting with observable and objective features such as the year and journal of publication, the industry and geographical distribution of firms studied and methodological aspects concerning data collection and analysis.

We now propose a classification according to the article aims. Although the authors of the articles explicitly stated their aims in detail, we attempted to synthesise these aims into groups of higher-level contributions to the SBM literature.

Table 7 shows the seven overarching categories that emerged from our classification of studies according to their aims. The first category, which refers to the proposal of frameworks and tools, included almost $40 \%$ of our article database, while the second category, SBM implementation examples, included approximately $23 \%$ of our database. This shows that the SBM literature has made two primary contributions: first, conceptual and visual models and practical tools for companies that explain how to integrate sustainability principles into traditional BMs (Bocken, Short, Rana \& Evans, 2013; Bocken, Rana \& Short, 2015; Vladimirova, 2019); and second, case studies as 
examples of companies that have succeeded in integrating sustainability into their traditional BMs to innovate and transform them into SBMs (Høgevold, 2011; Nisa, 2015; Matos \& Silvestre, 2013). Two other categories of articles that together constituted another $21 \%$ of our database were SBM component frameworks and SBM-specific archetypes. The first refers to all articles in which the authors, starting from Osterwalder et al.'s (2010) business model canvas, proposed new canvas models or other visual representations focusing mainly on the composition of SBMs, including value proposition, value creation, value distribution and value capture (Biloslavo et al., 2018; Joyce \& Paquin, 2016; Morioka et al., 2018). The SBM-specific archetypes category includes all articles focusing on specific types of SBM, including social business models, product service systems, sharing platforms, bottom-of-the-pyramid models or collaborative consumption BMs (Bittencourt Marconatto, Barin-Cruz, Pozzebon \& Poitras, 2016; Dobson, Boone, Andries \& Daou, 2018; Dreyer, B., Lüdeke-Freund, Hamann, \& Faccer, 2017; Yang, Evans, Vladimirova, \& Rana, 2017). Another type of SBM, the circular BM, was not analysed in this review because it was considered an autonomous stream of SBM literature. Three final categories were identified: the first included articles reviewing the literature on SBM and proposing new perspectives arising from the recognition of gaps in the literature (Geissdoerfer et al., 2018; De Souza, de Mello \& Marx, 2019; Nosratabadi, Mosavi, Shamshirband, Zavadskas, Rakotonirainy, \& Chau, 2019).; the second included articles focusing on the proposal of new classifications of SBM, such as types, archetypes, patterns or other taxonomies (Bocken et al., 2014; Lüdeke-Freund et al., 2018; Yip \& Bocken, 2018) ; and the third category, Editorial, included introductory articles in special issues that aimed to summarise the main themes presented by contributing authors (Arevalo et al., 2011; Dentchev et al., 2018; Schaltegger et al., 2016a).

Table 7. Study classification

\begin{tabular}{llc}
\hline Classification & Frequency & \% of Frequency \\
\hline Sustainable business model (SBM) tools and frameworks & 42 & $40.38 \%$ \\
SBM implementation examples & 24 & $23.08 \%$ \\
SBM component frameworks & 11 & $10.58 \%$ \\
SBM-specific archetypes & 10 & $9.62 \%$ \\
Reviews & 8 & $7.69 \%$ \\
SBM taxonomies & 5 & $4.81 \%$ \\
Editorials & 4 & $3.85 \%$ \\
Total & 104 & $100 \%$ \\
\hline
\end{tabular}

In addition to classifying the aims presented by various authors, the literature review also generated a number of article themes, which may be described as the perspective from which SBMs were analysed. The themes shown in Table 8 did not come from a predefined classification but rather emerged as articles were read before being reviewed and refined during the analysis process. Eight key themes emerged from the analysis of SBM articles.

Table 8. Article themes

\begin{tabular}{llc}
\hline Theme & Frequency & \% of Frequency \\
\hline Innovation & 44 & $42.31 \%$ \\
Societal/transition systems & 34 & $32.69 \%$ \\
Value & 34 & $32.69 \%$ \\
Collaborative/network & 25 & $24.04 \%$ \\
Design process & 11 & $10.58 \%$ \\
Evolution/life cycle & 5 & $4.81 \%$ \\
Scalability & 5 & $4.81 \%$ \\
Education & 2 & $1.92 \%$ \\
\hline
\end{tabular}

The most frequent theme presented in the articles (44 out of 104) was that of innovation (Carayannis, Sindakis \& Walter, 2015; Hu, Huang, Cheng \& Lu, 2019; Laukkanen \& Patala, 2014). These articles focused on the transition of BMs towards sustainability by identifying the barriers and obstacles rather than the opportunities an enterprise faces when deciding to introduce changes or totally reconsider its BM. 
The second most frequent theme, present in 34 articles of 104, was that of societal transition systems (Bolton \& Hannon, 2016), which refers to the transition of business ecosystems towards the implementation of sustainable development principles. In these cases, the focus was not just on a particular firm or BM but on the role that they play in the unavoidable transition towards a more sustainable society.

The third most frequent theme was that of value, which in the SBM literature typically includes not only financial value (as in traditional BMs) but also environmental and social dimensions of value. Some articles in this category proposed frameworks or analytical tools to identify the different types of value created or destroyed as well as distinguishing the different categories of stakeholders involved (Biloslavo et al., 2018; Bocken et al., 2013; Brehmer, Podoynitsyna \& Langerak, 2018; Yang et al., 2017).

The collaborative/network theme emerged in articles highlighting the need to reconsider the level of investigation in the SBM research (Dreyer et al., 2017; Rohrbeck, Konnertz, \& Knab, 2013; Rossignoli \& Lionzo, 2018). Given that many sustainability innovations stem from the collaboration of different actors and organisations, analyses that are limited to the BMs of single firms cannot capture this relevant aspect.

Another theme that emerged from our investigation is that of the design process, which pertains to articles establishing the necessary steps in the design of a new BM (Baldassarre, Calabretta, Bocken, \& Jaskiewicz, 2017; Geissdoerfer, Bocken, \& Jan, 2016). In most cases, these steps were defined using a creative and participatory process carried out through workshops or focus groups with firm managers and professional experts.

The next category in Table 8 concerns the various life cycle stages through which every BM goes, from the initial phase through to maturity, similar to the life cycle models proposed in the management literature for products or firms (Jabłoński, 2016; Short, Bocken, Barlow, \& Chertow, 2014).Two other themes emerged with lower frequency: first, scalability of BMs (Dobson et al., 2018; Jabłoński, 2016a; Täuscher \& Abdelkafi, 2018), which is the distribution of sustainability innovations to bring greater benefits to the environment and society while simultaneously assuring economic sustainability; and second, education, or how to disseminate awareness and information about SBMs through student engagement and the implementation of new university courses (Karlusch, Sachsenhofer \& Reinsberger, 2018).

\section{Discussion and Conclusion}

Although the SBM literature is recent, it has undergone rapid development. Most articles have been published by the Journal of Cleaner Production, which has recently hosted a substantial special issue on the theme. Articles have mainly approached the topic of SBM from a theoretical perspective, presenting frameworks, tools and taxonomies. In most cases, articles presented either the application of these frameworks or the ideation, formulation and implementation of tools and frameworks by firms and consultants/experts.

Empirical analyses have mainly used the case study methodology to investigate the practical implementation of SBMs. Some cases were based on secondary data, while interviews were used as the primary data collection method. Apart from these frequently used methods, the literature is characterised by some original and innovative methods, including workshops, focus groups and Delphi methods, which were used to collectively discuss topics and co-create new frameworks and tools. Quantitative studies were scant—considering the innovative nature of the topic, which requires a description of the few (but increasing) best practices, the large amount of data needed for quantitative analysis is difficult to obtain. Case studies and other kinds of empirical analyses focused on firms belonging to various industries, with manufacturing and energy sectors prevailing. Companies mainly originated from the United States or European countries such as United Kingdom, Germany and Netherlands.

The themes that emerged from this review show that most studies have been devoted to formulating new or modified frameworks and tools or implementing SBMs. The most frequent theme was that of innovation, which is to be expected given that the SBM literature has stemmed from the BM innovation and sustainability literature. Because sustainable development is a common goal for organisations, the study of the application of SBM appears to be related to a higher-level transition towards a more sustainable society. Thus, business can act as a lever to spread sustainable development knowledge and practical implementation.

The topic of SBM implies the consideration of values, which was another recurring topic in the literature. Many authors referred to SBM elements in terms of value proposition, creation, delivery and capture. However, if we examine the articles in more depth, we find many conceptualisations of value (especially value proposition and value creation), but concrete proposals for measuring value are missing. In particular, methods of combining the traditional financial model with the widely acknowledged need to extend the social and environmental dimensions of value have not yet been developed. If value capture is limited to revenues and costs, its SBM conceptualisation 
and representation will remain incomplete. Further, if sustainability is not measured or adequately reported in decision-making processes, firms will continue to be directed towards financial considerations.

Therefore, the development of the SBM literature can benefit from focusing on this topic, which has received little attention until now. We think that a possible motivation for this low attention could depend on two main factors: first, the intrinsic difficulty to represent sustainability value and performance in a synthetic way, as the BM representation usually requires; and second, the research fields of scholars devoted to SBM studies, which usually encompass management, engineering, design, environmental studies but rarely accounting studies To fill this gap scholars need to examine the relationship between the SBM literature and the existing literature on sustainability performance management and reporting. In this way, the strategic approach to sustainability suggested by SBMs may be connected with the managerial and accounting approach for its implementation and control.

\section{Acknowledgements}

This research is part of the project \#BIT Business Innovation \& Digital Transformation @ Vicenza, WP3 "Sustainable Business Models", funded by Fondazione Studi Universitari di Vicenza.

\section{References}

Abdelkafi, N., \& Täuscher, K. (2016). Business models for sustainability from a system dynamics perspective. Organization \& Environment, 29, 74-96. https://doi.org/10.1177/1086026615592930

Agafonow, A., \& Donaldson, C., \& Hoerber, T. (2015): Editorial: Unveiling the economic rationale behind the social business model. Social Business, 5, 1-4. https://doi.org/10.1362/204440815X14267607784686

Al-Saleh, Y., \& Mahroum, S. (2015). A critical review of the interplay between policy instruments and business models: Greening the built environment a case in point. Journal of Cleaner Production, 109, 260-270. https://doi.org/10.1016/j.jclepro.2014.08.042

American Psychological Association. (2001). Publication manual of the American Psychological Association (5th ed.). Washington, DC: American Psychological Association.

Arevalo, J. A., Castelló, I., de Colle, S., Lenssen, G., Neumann, K., \& Zollo, M. (2011): Introduction to the special issue: Integrating sustainability in business models. Journal of Management Development, 30, 941-951. https://doi.org/10.1108/02621711111182466

Baldassarre, B., Calabretta, G., Bocken, N. M. P., \& Jaskiewicz, T. (2017). Bridging sustainable business model innovation and user-driven innovation: A process for sustainable value proposition design. Journal of Cleaner Production, 147, 175-186. https://doi.org/10.1016/j.jclepro.2017.01.081

Biloslavo, R., Bagnoli, C., \& Edgar, D. (2018). An eco-critical perspective on business models: The value triangle as an approach to closing the sustainability gap. Journal of Cleaner Production, 174, 746-762. https://doi.org/10.1016/j.jclepro.2017.10.281

Bittencourt Marconatto, D. A., Barin-Cruz, L., Pozzebon, M., \& Poitras, J. E. (2016). Developing sustainable business models within BOP contexts: Mobilizing native capability to cope with government programs. Journal of Cleaner Production, 129, 735-748. https://doi.org/10.1016/j.jclepro.2016.03.038

Bocken, N., Boons, F., \& Baldassarre, B. (2019). Sustainable business model experimentation by understanding ecologies of business models. Journal of Cleaner Production, 208, 1498-1512. https://doi.org/10.1016/j.jclepro.2018.10.159

Bocken, N. M. P., Rana, P., \& Short, S. (2015). Value mapping for sustainable business thinking. Journal of Industrial and Production Engineering, 32, 67-81. https://doi.org/10.1080/21681015.2014.1000399

Bocken, N. M. P., Short, S., Rana, P., \& Evans, S. (2013). A value mapping tool for sustainable business modelling. Corporate Governance, 13, 482-497. https://doi.org/10.1108/CG-06-2013-0078

Bocken, N. M. P., Short, S. W., Rana, P., \& Evans, S. (2014). A literature and practice review to develop sustainable business model archetypes. Journal of Cleaner Production, 65, 42-56. https://doi.org/10.1016/j.jclepro.2013.11.039

Bolton, R., \& Hannon, M. (2016). Governing sustainability transitions through business model innovation: Towards a system understanding. Research Policy, 45, 1731-1742. https://doi.org/10.1016/j.respol.2016.05.003

Boons, F., \& Laasch, O. (2019). Business models for sustainable development: A process perspective. Journal of Business Models, 7(1), 9-12. https://doi.org/10.5278/ojs.jbm.v7i1.2164 
Boons, F., \& Lüdeke-Freund, F. (2013). Business models for sustainable innovation: State-of-the-art and steps towards a research agenda. Journal of Cleaner Production, 45, 9-19. https://doi.org/10.1016/j.jclepro.2012.07.007

Boons, F., Montalvo, C., Quist, J., \& Wagner, M. (2013). Sustainable innovation, business models and economic performance: An overview. Journal of Cleaner Production, 45, 1-8. https://doi.org/10.1016/j.jclepro.2012.08.013

Brehmer, M., Podoynitsyna, K., \& Langerak, F. (2018). Sustainable business models as boundary-spanning systems of value transfers. Journal of Cleaner Production, 172, 4514-4531. https://doi.org/10.1016/j.jclepro.2017.11.083

Breuer, H., \& Lüdeke-Freund, F. (2014). Normative innovation for sustainable business models in value networks. Paper presented at the XXV Innovation for Sustainable Economy \& Society Conference, Dublin, Ireland. Abstract retrieved from URL: https://ssrn.com/abstract $=2442937$

Breuer, H., \& Lüdeke-Freund, F. (2017). Values-based network and business model innovation. International Journal of Innovation Management, 21(3), 1750028. https://doi.org/10.1142/S1363919617500281

Carayannis, E. G., Sindakis, S., \& Walter, C. (2015). Business model innovation as lever of organizational sustainability. The Journal of Technology Transfer, 40, 85-104. https://doi.org/10.1007/s10961-013-9330-y

Davies, I. A., \& Chambers, L. (2018). Integrating hybridity and business model theory in sustainable entrepreneurship. Journal of Cleaner Production, 177, 378-386. https://doi.org/10.1016/j.jclepro.2017.12.196

Dentchev, N., Rauter, R., Dieleman, H., Jòhannsdòttir, L., Snihur, Y., Rosano, M., . . . Jonker, J. (2018). Embracing the variety of sustainable business models: A prolific field of research and a future agenda. Journal of Cleaner Production, 194, 695-703. https://doi.org/10.1016/j.jclepro.2018.05.156

de Souza, J. V. R., de Mello, A. M., \& Marx, R. (2019). When is an innovative urban mobility business model sustainable? A literature review and analysis. Sustainability, 11, 1761. https://doi.org/10.3390/su11061761

Dickson, M. A., \& Chang, R. (2015). Apparel manufacturers and the business case for social sustainability: 'World class' CSR and business model innovation. Journal of Corporate Citizenship, (57), 55-72. https://doi.org/10.9774/gleaf.4700.2015.ma.00006

Dobson, K., Boone, S., Andries, P., \& Daou, A. (2018). Successfully creating and scaling a sustainable social enterprise model under uncertainty: The case of ViaVia Travellers Cafés. Journal of Cleaner Production, 177, 82-95. https://doi.org/10.1016/j.jclepro.2017.11.067

Dohrmann, S., Raith, M., \& Siebold, N. (2015). Monetizing social value creation - a business model approach. Entrepreneurship Research Journal, 5, 127-154. https://doi.org/10.1515/erj-2013-0074

Dreyer, B., Lüdeke-Freund, F., Hamann, R., \& Faccer, K. (2017). Upsides and downsides of the sharing economy: Collaborative consumption business models' stakeholder value impacts and their relationship to context. Technological Forecasting and Social Change, 125, 87-104. https://doi.org/10.1016/j.techfore.2017.03.036

Duran-Encalada, J. A., \& Paucar-Caceres, A. (2012). A system dynamics sustainable business model for Petroleos Mexicanos (Pemex): Case based on the Global Reporting Initiative. Journal of the Operational Research Society, 63, 1065-1078. https://doi.org/10.1057/jors.2011.115

Ehrenfeld, J. R. (2000). Being and havingness. Forum for Applied Research and Public Policy, 15(4), 35-41.

Elkington, R., \& Upward, A. (2016). Leadership as enabling function for flourishing by design. Journal of Global Responsibility, 7, 126-144. https://doi.org/10.1108/jgr-01-2016-0002

Evans, S., Vladimirova, D., Holgado, M., Van Fossen, K., Yang, M., Silva, E. A., \& Barlow, C. Y. (2017). Business model innovation for sustainability: Towards a unified perspective for creation of sustainable business models. Business Strategy and the Environment, 26, 597-608. https://doi.org/10.1002/bse.1939

França, C. L., Broman, G., Robèrt, K. H., Basile, G., \& Trygg, L. (2017). An approach to business model innovation and design for strategic sustainable development. Journal of Cleaner Production, 140, 155-166. https://doi.org/10.1016/j.jclepro.2016.06.124

Gallo, J. P., Antolin-Lopez, R., \& Montiel, I. (2018). Associative sustainable business models: Cases in the bean-to-bar chocolate industry. Journal of Cleaner Production, 174, 905-916. https://doi.org/10.1016/j.jclepro.2017.11.021 
Gauthier, C., \& Gilomen, B. (2016). Business models for sustainability: Energy efficiency in urban districts. Organization \& Environment, 29, 124-144. https://doi.org/10.1177/1086026615592931

Geissdoerfer, M., Bocken, N. M. P., \& Jan, E. (2016). Design thinking to enhance the sustainable business modelling process - a workshop based on a value mapping process. Journal of Cleaner Production, 135, 1218-1232. https://doi.org/10.1016/j.jclepro.2016.07.020

Geissdoerfer, M., Vladimirova, D., \& Evans, S. (2018). Sustainable business model innovation: A review. Journal of Cleaner Production, 198, 401-416. https://doi.org/10.1016/j.jclepro.2018.06.240

Hellström, M., Tsvetkova, A., Gustafsson, M., \& Wikström, K. (2015). Collaboration mechanisms for business models in distributed energy ecosystems. Journal of Cleaner Production, 102, 226-236. https://doi.org/10.1016/j.jclepro.2015.04.128

Hemphill, T. A. (2013). The global food industry and 'creative capitalism': The partners in food solutions sustainable business model. Business and Society Review, 118, 489-512. https://doi.org/10.1111/basr.12019

Høgevold, N. M. (2011). A corporate effort towards a sustainable business model. European Business Review, 23, 392-400. https://doi.org/10.1108/09555341111145771

Hoveskog, M., Halila, F., Mattsson, M., Upward, A., \& Karlsson, N. (2018). Education for Sustainable development: Business modelling for flourishing. Journal of Cleaner Production, 172, 4383-4396. https://doi.org/10.1016/j.jclepro.2017.04.112

Hu, H., Huang, T., Cheng, Y., \& Lu, H. (2019). The evolution of sustainable business model innovation: Evidence from a sharing economy platform in China. Sustainability, 11, 4207. https://doi.org/10.3390/su11154207

Hutchinson, D., Singh, J., \& Walker, K. (2012). An assessment of the early stages of a sustainable business model in the Canadian fast food industry. European Business Review, 24, 519-531. https://doi.org/10.1108/09555341211270537

Hvass, K. K. (2015). Business model innovation through second hand retailing: A fashion industry case. Journal of Corporate Citizenship, (57), 11-32. https://doi.org/10.9774/gleaf.4700.2015.ma.00004

Iles, A., \& Martin, A. N. (2013). Expanding bioplastics production: Sustainable business innovation in the chemical industry. Journal of Cleaner Production, 45, 38-49. https://doi.org/10.1016/j.jclepro.2012.05.008

Jabłoński, A. (2016a). Scalability of sustainable business models in hybrid organizations. Sustainability, 8, 194. https://doi.org/10.3390/su8030194

Jabłoński, A. (Ed.). (2016b). Sustainable business models [Special issue]. Sustainability, 7/8. https://doi.org/10.3390/books978-3-03897-561-8

Jabłoński A., \& Jabłoński, M. (2016). Research on business models in their life cycle. Sustainability, 8, 430. https://doi.org/10.3390/su8050430

Jing, H., \& Jiang, B. S. (2013). The framework of green business model for eco-innovation. Journal of Supply Chain and Operations Management, 11(1), 33-46.

Joyce, A., \& Paquin, R. L. (2016). The triple layered business model canvas: A tool to design more sustainable business models. Journal of Cleaner Production, 135, 1474-1486. https://doi.org/10.1016/j.jclepro.2016.06.067

Karlsson, N. P. E., Hoveskog, M., Halila, F., \& Mattsson, M. (2018). Early phases of the business model innovation process for sustainability: Addressing the status quo of a Swedish biogas-producing farm cooperative. Journal of Cleaner Production, 172, 2759-2772. https://doi.org/10.1016/j.jclepro.2017.11.136

Karlusch, A., Sachsenhofer, W., \& Reinsberger, K. (2018). Educating for the development of sustainable business models: Designing and delivering a course to foster creativity. Journal of Cleaner Production, 179, 169-179. https://doi.org/10.1016/j.jclepro.2017.12.199

Kozlowski, A., Searcy, C., \& Bardecki, M. 2018. The reDesign canvas: Fashion design as a tool for sustainability. Journal of Cleaner Production, 183, 194-207. https://doi.org/10.1016/j.jclepro.2018.02.014

Kudak, R., Martinuzzi, A., Schnherr, N., \& Krumay, B. (2015). Quo vadis responsible fashion?: Contingencies and trends influencing sustainable business models in the wearing apparel sector. Journal of Corporate Citizenship, 2015(57), 33-54. https://doi.org/10.9774/gleaf.4700.2015.ma.00005 
Kurucz, E. C., Colbert, B. A., Lüdeke-Freund, F., Upward, A., \& Willard, B. (2017). Relational leadership for strategic sustainability: Practices and capabilities to advance the design and assessment of sustainable business models. Journal of Cleaner Production, 140, 189-204. https://doi.org/10.1016/j.jclepro.2016.03.087

Laasch, O. (2018). Beyond the purely commercial business model: Organizational value logics and the heterogeneity of sustainability business models. Long Range Planning, 51, 158-183. https://doi.org/10.1016/j.lrp.2017.09.002

Lambert, S. (2018). Applying a sustainability lens to the business model. Journal of Business Models, 6(2), 49-53.

Laukkanen, M., \& Patala, S. (2014). Analysing barriers to sustainable business model innovations: Innovation system approach. International Journal of Innovation Management, 18(6), 1440010. https://doi.org/10.1142/s1363919614400106

Long, T. B., Looijen, A., \& Blok, V. (2018). Critical success factors for the transition to business models for sustainability in the food and beverage industry in the Netherlands. Journal of Cleaner Production, 175, 82-95. https://doi.org/10.1016/j.jclepro.2017.11.067

Lozano, R. (2018). Sustainable business models: Providing a more holistic perspective. Business Strategy and the Environment, 27, 1159-1166. https://doi.org/10.1002/bse.2059

Luciano, T. (2011). Doing a literature review: Releasing the social science research imagination. Evaluation \& Research in Education, 24, 303-304. https://doi.org/10.1080/09500790.2011.588012

Lüdeke-Freund, F., Carroux, S., Joyce, A., Massa, L., \& Breuer, H. (2018). The sustainable business model pattern taxonomy -45 patterns to support sustainability-oriented business model innovation. Sustainable Production and Consumption, 15, 145-162. https://doi.org/10.1016/j.spc.2018.06.004

Lüdeke-Freund, F., \& Dembek, K. (2017). Sustainable business model research and practice: Emerging field or passing fancy? Journal of Cleaner Production, 168, 1668-1678. https://doi.org/10.1016/j.jclepro.2017.08.093

Matos, S., \& Silvestre, B. S. (2013). Managing stakeholder relations when developing sustainable business models: The case of the Brazilian energy sector. Journal of Cleaner Production, 45, 61-73. https://doi.org/10.1016/j.jclepro.2012.04.023

Molderez, I., \& van Elst, B. (2015). Barriers towards a systemic change in the clothing industry: How do sustainable fashion enterprises influence their sector? Journal of Corporate Citizenship, (57), 99-114. https://doi.org/10.9774/gleaf.4700.2015.ma.00008

Moratis, L., Melissen, F., \& Idowu, S. O. (2018). Sustainable business models: Principles, promise, and practice. Cham, Switzerland: Springer.

Morgan, E. (2015). Plan A: Analysing business model innovation for sustainable consumption in mass-market clothes retailing. Journal of Corporate Citizenship, (57), 73-98. https://doi.org/10.9774/gleaf.4700.2015.ma.00007

Morioka, S. N., Bolis, I., Evans, S., \& Carvalho, M. M. (2017). Transforming sustainability challenges into competitive advantage: Multiple case studies kaleidoscope converging into sustainable business models. Journal of Cleaner Production, 167, 723-738. https://doi.org/10.1016/j.jclepro.2017.08.118

Morioka S. N., Bolis, I., Monteiro, M., \& Carvalho, M. M. (2018). From an ideal dream towards reality analysis: Proposing sustainable value exchange matrix (SVEM) from systematic literature review on sustainable business models and face validation. Journal of Cleaner Production, 178, 76-88. https://doi.org/10.1016/j.jclepro.2017.12.078

Morioka, S. N., Evans, S., \& Carvalho, M. M. (2016). Sustainable business model innovation: Exploring evidences in sustainability reporting. Procedia CIRP, 40, 660-668. https://doi.org/10.1016/j.procir.2016.01.151

Neumeyer, X., \& Santos, S. C. (2018). Sustainable business models, venture typologies, and entrepreneurial ecosystems: A social network perspective. Journal of Cleaner Production, 172, 4565-4579. https://doi.org/10.1016/j.jclepro.2017.08.216

Nielsen, C., Lund, M., Thomsen, P., Brøndum, K., Sort, J., Byrge, C., ... Dumay, J. (2018). Depicting a performative research agenda: The 4th stage of business model research. Journal of Business Models, 6(2), 59-64. https://doi.org/10.5278/ojs.jbm.v6i2.2465 
Nisa, S. (2015). Inter-firm differences in the sustainability business model: A study on select firms from agri-food and IT companies. IUP Journal of Business Strategy, XII(4), 35-55.

Nosratabadi, S., Mosavi, A., Shamshirband, S., Zavadskas, E. K., Rakotonirainy, A., \& Chau, K. W. (2019). Sustainable business models: A review. Sustainability, 11, 1663. https://doi.org/10.3390/su11061663

Olofsson, S., Hoveskog, M., \& Halila, F. (2018). Journey and impact of business model innovation: The case of a social enterprise in the Scandinavian electricity retail market. Journal of Cleaner Production, 175, 70-81. https://doi.org/10.1016/j.jclepro.2017.11.081

Oskam, I., Bossink, B., \& de Man, A.-P. (2018). The interaction between network ties and business modeling: Case studies of sustainability-oriented innovations. Journal of Cleaner Production, 177, 555-566. https://doi.org/10.1016/j.jclepro.2017.12.202

Osterwalder, A., Pigneur, Y., \& Tucci, C. L. (2010). Clarifying business models: Origins, present, and future of the concepts. Communications of the Association for Information Systems, 16, 1-40. https://doi.org/10.17705/1 cais.01601

Palomares-Aguirre, I., Barnett, M., Layrisse, F., \& Husted, B. W. (2018). Built to scale? How sustainable business models can better serve the base of the pyramid. Journal of Cleaner Production, 172, 4506-4513. https://doi.org/10.1016/j.jclepro.2017.11.084

Pedersen, E., \& Gardetti, M. (Eds.). (2015). New business models for sustainable fashion [Special issue]. Journal of Corporate Citizenship, 215(57).

Pedersen, E. R. G., Gwozdz, W., \& Hvass, K. K. (2018). Exploring the relationship between business model innovation, corporate sustainability, and organizational values within the fashion industry. Journal of Business Ethics, 149, 267-284. https://doi.org/10.1007/s10551-016-3044-7

Pedersen, E. R. G., \& Netter, S. (2015). Collaborative consumption: Business model opportunities and barriers for fashion libraries. Journal of Fashion Marketing and Management, 19, 258-273. https://doi.org/10.1108/JFMM-05-2013-0073

Peppou, G. (2018). Biotechnology-driven business model archetypes: Sustainability, innovation and commercial viability. Journal of Commercial Biotechnology, 24(3), 41-56. https://doi.org/10.5912/jcb840

Raith, M. G., \& Siebold, N. (2018). Building business models around sustainable development goals. Journal of Business Models, 6(2), 71-77. https://doi.org/10.5278/ojs.jbm.v6i2.2467

Rajala, R., Westerlund, M., \& Lampikoski, T. (2016). Environmental sustainability in industrial manufacturing: Re-examining the greening of Interface's business model. Journal of Cleaner Production, 115, 52-61. https://doi.org/10.1016/j.jclepro.2015.12.057

Randles, S., \& Laasch, O. (2016). Theorising the normative business model. Organization \& Environment, 29, 53-73. https://doi.org/10.1177/1086026615592934

Rauter, R., Jonker, J., \& Baumgartner, R. J. (2017). Going one's own way: Drivers in developing business models for sustainability. Journal of Cleaner Production, 140, 144-154. https://doi.org/10.1016/j.jclepro.2015.04.104

Ray, A., \& Mondal, S. (2017). Study of collaborative PRM business model for sustainability. Benchmarking: An International Journal, 24, 1891-1911. https://doi.org/10.1108/bij-04-2016-0048

Ribeiro, I., Sobral, P., Peças, P., \& Henriques, E. (2018). A sustainable business model to fight food waste. Journal of Cleaner Production, 177, 262-275. https://doi.org/10.1016/j.jclepro.2017.12.200

Richardson, J. E. (2008). The business model: An integrative framework for strategy execution. Strategic Change, 144, 133-144. https://doi.org/10.1002/jsc. 821

Ritala, P., Huotari, P., Bocken, N., Albareda, L., \& Puumalainen, K. (2018). Sustainable business model adoption among S\&P 500 firms: A longitudinal content analysis study. Journal of Cleaner Production, 170, 216-226. https://doi.org/10.1016/j.jclepro.2017.09.159

Rohrbeck, R., Konnertz L., \& Knab. S. (2013). Collaborative business modelling for systemic and sustainability innovations. International Journal of Technology Management, 63, 4. https://doi.org/10.1504/ijtm.2013.055577 
Roome, N., \& Louche, C. (2016). Journeying toward business models for sustainability: A conceptual model found inside the black box of organisational transformation. Organization \& Environment, 29, 11-35. https://doi.org/10.1177/1086026615595084

Rossignoli, F., \& Lionzo, A. (2018). Network impact on business models for sustainability: Case study in the energy sector. Journal of Cleaner Production, 182, 694-704. https://doi.org/10.1016/j.jclepro.2018.02.015

Rotondo, F., Corsi, K., \& Giovanelli, L. (2019). The social side of sustainable business models: An explorative analysis of the low-cost airline industry. Journal of Cleaner Production, 225, 806-819. https://doi.org/10.1016/j.jclepro.2019.03.345

Schaltegger, S., Hansen, E. G., \& Lüdeke-Freund, F. (Eds.). (2016a). Business models for sustainability: Entrepreneurship, innovation and transformation [Special issue]. Organization \& Environment, 29(1).

Schaltegger, S., Hansen, E. G., \& Lüdeke-Freund, F. (2016b). Business models for sustainability: Origins, present research, and future avenues. Organization \& Environment, 29, 3-10. https://doi.org/10.1177/1086026615599806

Schaltegger, S., Lüdeke-Freund, F., \& Hansen, E. G. (2012). Business cases for sustainability and the role of business model innovation. International Journal of Innovation and Sustainable Development, 6, 95-119. https://doi.org/10.1504/ijisd.2012.046944

Schaltegger, S., Lüdeke-Freund, F., \& Hansen, E. G. (2016). Business models for sustainability: A co-evolutionary analysis of sustainable entrepreneurship, innovation, and transformation. Organization \& Environment, 29, 264-289. https://doi.org/10.1177/1086026616633272

Seuring, S., \& Müller, M. (2008). From a literature review to a conceptual framework for sustainable supply chain management. Journal of Cleaner Production, 16, 1699-1710. https://doi.org/10.1016/j.jclepro.2008.04.020

Short, S. W., Bocken, N. M. P., Barlow, C. Y., \& Chertow, M. R. (2014). From refining sugar to growing tomatoes: Industrial ecology and business model evolution. Journal of Industrial Ecology, 18, 603-617. https://doi.org/10.1111/jiec.12171

Shumate, M., Hsieh, Y. P., \& O’Connor, A. (2016). A nonprofit perspective on business-nonprofit partnerships: Extending the symbiotic sustainability model. Business \& Society, 57, 1337-1373. https://doi.org/10.1177/0007650316645051

Shumate, M., \& O’Connor, A. (2010). The symbiotic sustainability model: Conceptualizing NGO-corporate alliance communication. Journal of Communication, 60, 577-609. https://doi.org/10.1111/j.1460-2466.2010.01498

Small-Warner, K., Abuzeinab, A., \& Taki, A. (2018). A review of sustainable business models and strategic sustainable development. Journal of Business Models, 6(2), 84-89.

Sousa-Zomer, T. T., \& Cauchick-Miguel, P. A. (2018). Sustainable business models as an innovation strategy in the water sector: An empirical investigation of a sustainable product-service system. Journal of Cleaner Production, 171, S119-S129. https://doi.org/10.1016/j.jclepro.2016.07.063

Stubbs, W. (2019). Strategies, practices, and tensions in managing business model innovation for sustainability: The case of an Australian BCorp. Corporate Social Responsibility and Environmental Management, 26, 1063-1072. https://doi.org/10.1002/csr.1786

Stubbs, W., \& Cocklin, C. (2008). Conceptualizing a 'sustainable business model'. Organization \& Environment, 21, 103. https://doi.org/10.1177/1086026608318042

Svensson, G., \& Wagner, B. (Eds.). (2011): Sustainable business models [Special issue]. European Business Review, 23(4).

Täuscher, K., \& Abdelkafi, N. (2018). Scalability and robustness of business models for sustainability: A simulation experiment. Journal of Cleaner Production, 170, 654-664. https://doi.org/10.1016/j.jclepro.2017.09.023

Tolkamp, J., Huijben, J. C. C. M., Mourik, R. M., Verbong, G. P. J., \& Bouwknegt, R. (2018). User-centred sustainable business model design: The case of energy efficiency services in the Netherlands. Journal of Cleaner Production, 182, 755-764. https://doi.org/10.1016/j.jclepro.2018.02.032

Torraco, R. J. (2005). Writing integrative literature reviews: Guidelines and examples. Human Resource Development Review, 4, 356-367. https://doi.org/10.1177/1534484305278283 
Tranfield, D., Denyer, D., \& Smart, P. (2003). Towards a methodology for developing evidence-informed management knowledge by means of systematic review. British Journal of Management, 14, 207-222. https://doi.org/10.1111/1467-8551.00375

Tukker, A. (2004). Eight types of product-service system: Eight ways to sustainability? Experiences from SusProNet. Business Strategy and the Environment, 13, 246-260. https://doi.org/10.1002/bse.414

United Nations. (2015). Transforming our world: The 2030 agenda for sustainable development. New York, NY: United Nations.

Upward, A., \& Jones, P. (2016). An ontology for strongly sustainable business models: Defining an enterprise framework compatible with natural and social science. Organization \& Environment, 29, 97-123. https://doi.org/10.1177/1086026615592933

van Bommel, K. (2018). Managing tensions in sustainable business models: Exploring instrumental and integrative strategies. Journal of Cleaner Production, 196, 829-841. https://doi.org/10.1016/j.jclepro.2018.06.063

Vladimirova, D. (2019). Building sustainable value propositions for multiple stakeholders: A practical tool. Journal of Business Models, 7(1), 1-8. https://doi.org/10.5278/ojs.jbm.v7i1.2103

Wadin, J. L., \& Ahlgren, K. (2019). Business models for sustainability-change in dynamic environments. Journal of Business Models, 7(1), 13-38.

Wadin, J. L., Ahlgren, K., \& Bengtsson, L. (2017). Joint business model innovation for sustainable transformation of industries - A large multinational utility in alliance with a small solar energy company. Journal of Cleaner Production, 160, 139-150. https://doi.org/10.1016/j.jclepro.2017.03.151

Wells, P. (2016). Economies of scale versus small is beautiful: A business model approach based on architecture, principles and components in the beer industry. Organization \& Environment, 29, 36-52. https://doi.org/10.1177/1086026615590882

Witek-Hajduk, M. K., \& Zaborek, P. (2016). Does business model affect CSR involvement? A survey of Polish manufacturing and services companies. Sustainability, 8, 93. https://doi.org/10.3390/su8020093

World Commission on Environment and Development. (1987). Our common future [Adobe Digital Editions version]. Oxford, United Kingdom: Oxford University Press. Retrieved from http://www.un-documents.net/our-common-future.pdf

Yang, M., Evans, S., Vladimirova, D., \& Rana, P. (2017). Value uncaptured perspective for sustainable business model innovation. Journal of Cleaner Production, 140, 1794-1804. https://doi.org/10.1016/j.jclepro.2016.07.102

Yip, A. W. H., \& Bocken, N. M. P. (2018). Sustainable business model archetypes for the banking industry. Journal of Cleaner Production, 174, 150-169. https://doi.org/10.1016/j.jclepro.2017.10.190

Yunus, M., Moingeon, B., \& Lehmann-Ortega, L. (2010). Building social business models: Lessons from the Grameen experience. Long Range Planning, 43, 308-325. https://doi.org/10.1016/j.lrp.2009.12.005

\section{Copyrights}

Copyright for this article is retained by the author(s), with first publication rights granted to the journal.

This is an open-access article distributed under the terms and conditions of the Creative Commons Attribution license (http://creativecommons.org/licenses/by/4.0/). 